\title{
Synthesis, characterization and thermal behaviour of solid-state compounds of heavy trivalent lanthanide and yttrium mandelates
}

\author{
A.C. Gigante", D.J.C. Gomes, L.S. Lima, F.J. Caires, O. Treu-Filho, M. Ionashiro \\ Instituto de Química, Universidade Estadual Paulista, CP 355, 14801-970, Araraquara, SP, Brazil.
}

Received 30/07/2014; accepted 04/09/2014

Available online $30 / 12 / 2014$

\begin{abstract}
Characterization, thermal stability and thermal decomposition of heavy trivalent lanthanide mandelates $\operatorname{Ln}\left(\mathrm{C}_{6} \mathrm{H}_{5} \mathrm{CH}(\mathrm{OH}) \mathrm{CO}_{2}\right)_{3} \cdot 2 \mathrm{H}_{2} \mathrm{O}(\mathrm{Ln}=$ $\mathrm{Tb}$ to $\mathrm{Lu}$ and $\mathrm{Y}$ ) were investigated employing simultaneous thermogravimetry and differential thermal analysis (TG-DTA), differential scanning calorimetry (DSC), experimental and theoretical infrared spectroscopy, X-ray diffractometry, complexometry and TG-DSC coupled to FTIR. The dehydration of the compounds occurs in a single step and the thermal decomposition of the anhydrous ones occurs in two, three, four or five consecutive steps, with formation of the respective oxides $\mathrm{Tb}_{4} \mathrm{O}_{7}$ and $\mathrm{Ln}_{2} \mathrm{O}_{3}(\mathrm{Ln}=\mathrm{Dy}$ to $\mathrm{Lu}$ and $\mathrm{Y}$ ) as final residues. The results also provided information concerning the composition, thermal behavior and gaseous products evolved during the thermal decomposition of these compounds. The theoretical and experimental spectroscopic data suggest the possible modes of coordination of the ligand with the heavy lanthanides.
\end{abstract}

Keywords: heavy trivalent lanthanides and yttrium; mandelate; thermal behavior; theoretical infrared spectroscopy.

\section{Introduction}

A survey of literature shows that the thermal studies involving lanthanide(III) and yttrium(III) ions is lacking and the papers published until nowadays are concerned to the stability of some lanthanide complexes with mandelate and atrolactate [1], the complexation of lanthanide ions with mandelate [2], preparation and some properties of lanthanum, neodymium and yttrium mandelates [3] , synthesis and study of the properties of yttrium subgroup rare earth hydroxyphenylacetates [4] and bonding trends in lanthanide mandelates [5]. Some studies related to successive formations constants [6], calorimetric titration of complexation of lanthanide mandelates with 1,10-phenanthroline [7], kinetics of complexation []], preparation and structural analysis of lanthanide complexes with $\alpha$-hydroxyphenylacetic acid and 1,10-phenanthroline as ligands [9], synthesis, crystal and spectroscopic studies of some lanthanides [10-12] and synthesis, thermal properties and spectroscopic study of solid mandelate of light trivalent lanthanides [13] were also reported.

As a continuation of our previous study [13], since our papers involving solid compounds with trivalent lanthanides and several organic ligands, the profiles of TG and DTA curves, as well as the thermal behaviour have shown similar characteristics among the light and heavy trivalent lanthanide compounds [14-19]. The present paper deals with the preparation of solid-state compounds of heavy trivalent lanthanides (i.e. Tb, Dy, Ho, Er, Tm, Yb, Lu) and yttrium with mandelate and its investigation by means of complexometry, elemental analysis, infrared spectroscopy (FTIR), simultaneous thermogravimetry and differential thermal analysis (TG-DTA), differential scanning calorimetry (DSC) and TG-DSC coupled to FTIR. The results allowed us to acquire information concerning these compounds in the solid-state, including their thermal stability and thermal decomposition.

\section{Experimental}

\subsection{Material and Methods}

The mandelic acid $\left(\mathrm{C}_{6} \mathrm{H}_{5} \mathrm{CH}(\mathrm{OH}) \mathrm{CO}_{2} \mathrm{H}\right)$ with $99 \%$ purity was obtained from Aldrich. Aqueous solution of sodium mandelate $0.10 \mathrm{~mol} \mathrm{~L}^{-1}$ was prepared by the neutralization of aqueous solution of mandelic acid with sodium hydroxide solution $0.10 \mathrm{~mol} \mathrm{~L}^{-1}$.

Lanthanide chlorides were prepared from the corresponding metal oxides (except for yttrium) by treatment with concentrated hydrochloric acid. The resulting solutions were evaporated to near dryness to eliminate the excess of hydrochloric acid. The residues were dissolved in distilled water and diluted in order to obtain ca. $0.10 \mathrm{~mol} \mathrm{~L}^{-1}$ solutions, whose $\mathrm{pH}$ were adjusted to 5.0 by adding diluted sodium hydroxide or hydrochloric acid solutions. Yttrium(III) was used as its chloride and ca. $0.10 \mathrm{~mol} \mathrm{~L}^{-1}$ aqueous solution of this ion was prepared by direct weighing of the salt.

Solid-state compounds were obtained by adding slowly with continuous stirring $150.0 \mathrm{~mL}$ of sodium mandelate solution $0.10 \mathrm{~mol} \mathrm{~L}^{-1}$ to $50.0 \mathrm{~mL}$ of the respective metal ions solutions $0.10 \mathrm{~mol} \mathrm{~L}^{-1}$, both heated up to near ebullition. After cooled at ambient temperature, the precipitates were washed with distilled water until chloride ions were eliminated, filtered and dried at $50{ }^{\circ} \mathrm{C}$ in a forced 
circulation air oven during $12 \mathrm{~h}$ and maintained in a desiccator over anhydrous calcium chloride.

In the solid-state, metal ions, hydration water and mandelate contents were determined from TG curves. The metal ions were also determined by complexometry with standard EDTA solution after igniting the compounds to the respective oxides and their dissolution in hydrochloric acid solution $[\underline{14}, \underline{15}]$.

Carbon and hydrogen contents were determined by calculation based on the mass losses observed in the TG curves, since the hydration water and ligand lost during the thermal decomposition occur with the formation of the respective oxides with stoichiometry known, as final residues.

X-ray powder patterns were obtained by using a Siemens D-5000 X-Ray Diffractometer employing CuK $\alpha$ radiation $(\lambda=1.541 \AA)$ and setting of $40 \mathrm{kV}$ and $20 \mathrm{~mA}$.

The attenuate total reflectance infrared spectra for sodium mandelate and for its metal-ion compounds were run on a Nicolet iS10 FTIR spectrophotometer, using ATR accessory with Ge window. The FTIR spectra were recorded with 32 scans per spectrum at resolution of $4 \mathrm{~cm}^{-1}$.

Simultaneous TG-DTA and DSC curves were obtained with two thermal analysis systems, model SDT 2960 and Q10, both from TA Instruments, and the purge gas was an air flow of 100 and $50 \mathrm{~mL} \mathrm{~min}^{-1}$, respectively. A heating rate of $10{ }^{\circ} \mathrm{C} \mathrm{min}^{-1}$ was adopted, with samples weighing about $7 \mathrm{mg}$ for TG-DTA and about $2 \mathrm{mg}$ for DSC. Alumina and aluminum crucibles, the latter with perforated cover, were used for recording the TG-DTA and DSC curves, respectively.

The measurements of the gaseous products were carried out using a TG-DSC1 Mettler Toledo coupled to a FTIR spectrophotometer Nicolet with gas cell and DTGS $\mathrm{KBr}$ detector. The furnace and the heated gas cell $\left(250{ }^{\circ} \mathrm{C}\right)$ were coupled through a heated $\left(200{ }^{\circ} \mathrm{C}\right) 120 \mathrm{~cm}$ stainless steel line transfer with diameter of $3 \mathrm{~mm}$, both purged with dry air $\left(50 \mathrm{~mL} \mathrm{~min}^{-1}\right)$. The FTIR spectra were recorded with 16 scans per spectrum at a resolution of $4 \mathrm{~cm}^{-1}$.

\subsection{Computational strategy}

In this study, the employed quantum chemical approach to determine the molecular structures was Becke three parameter hybrid theory [16] using the Lee-Yang-Par (LYP) correlation functional [17], and the basis sets used for calculations were: $4 \mathrm{~s}$ for $\mathrm{H}\left({ }^{2} \mathrm{~S}\right)[\underline{18}],[5 \mathrm{~s} 4 \mathrm{p}]$ for $\mathrm{C}\left({ }^{3} \mathrm{P}\right)$ and $\mathrm{O}$ $\left({ }^{3} \mathrm{P}\right)[18]$, and $[14 \mathrm{~s} 7 \mathrm{p} 7 \mathrm{~d}]$ for $\mathrm{Y}\left({ }^{2} \mathrm{D}\right)[19]$. The diffuse functions for the yttrium atom $\left({ }^{2} \mathrm{D}\right)$ were calculated according to the procedure described in Ref. [18] and these values are: $\alpha \mathrm{s}=0.007007235, \alpha p=0.991840315$, $\alpha \mathrm{d}=0.008880095$.

In order to better describe the properties of the compound in the implementation of the calculations, it was necessary to include polarization functions $[\underline{18}, \underline{19}, \underline{20]}$ for all atoms of the compound.

The polarization functions are: $\alpha p=0.33353749$ for $\mathrm{H}\left({ }^{2} \mathrm{~S}\right), \alpha \mathrm{d}=0.72760279$, and $\alpha \mathrm{d}=0.36059494$ for $\mathrm{C}\left({ }^{3} \mathrm{P}\right), \mathrm{O}$ $\left({ }^{3} \mathrm{P}\right)$, respectively, and $\alpha \mathrm{f}=0.394056689$ for $\mathrm{Y}\left({ }^{2} \mathrm{D}\right)$ atoms. The role of a basis set is a crucial point in theoretical studies of metal complexes, since the description of the configuration of the metal in the complex differs from the neutral state. The performed molecular calculations in this study were done using the Gaussian 09 routine [21].

The theoretical infrared spectrum was calculated using a harmonic field [22] based on $\mathrm{C}_{1}$ symmetry (electronic state ${ }^{1} \mathrm{~A}$ ). Frequency values (not scaled), relative intensities, assignments and description of vibrational modes are presented. The geometry optimization was computed using the optimized algorithm of Berny and the calculations of vibrational frequencies were also implemented to determine an optimized geometry constitutes minimum or saddle points [23]. The principal infrared active fundamental modes assignments and descriptions were done by the Gauss View 5.0.2 W graphics routine [24].

\section{Results and Discussion}

The analytical and thermoanalytical (TG) results are shown in Table 1. These data establish the stoichiometry of these compounds, which are in agreement with the general formula $\mathrm{Ln}(\mathrm{L})_{3} \cdot 2 \mathrm{H}_{2} \mathrm{O}$, where $\mathrm{Ln}$ represents trivalent terbium to lutetium and yttrium ions and $\mathrm{L}$ is mandelate.

Table 1 Analytical and thermoanalytical (TG) data for $\mathrm{Ln}(\mathrm{L})_{3} \cdot 2 \mathrm{H}_{2} \mathrm{O}$.

\begin{tabular}{|c|c|c|c|c|c|c|c|c|c|c|c|c|}
\hline \multirow{2}{*}{ Compounds } & \multicolumn{3}{|c|}{ Ln (oxide) / \% } & \multicolumn{2}{|c|}{$\mathrm{L}$ (lost) / \% } & \multicolumn{2}{|c|}{$\mathrm{H}_{2} \mathrm{O} / \%$} & \multicolumn{2}{|c|}{$\mathrm{C} / \%$} & \multicolumn{2}{|c|}{$\mathrm{H} / \%$} & \multirow{2}{*}{ Final Residue } \\
\hline & Calcd. & $\mathrm{TG}$ & EDTA & Calcd. & TG & Calcd. & $\mathrm{TG}$ & Calcd. & TG & Calcd. & TG & \\
\hline $\mathrm{Tb}(\mathrm{L})_{3} \cdot 2 \mathrm{H}_{2} \mathrm{O}$ & 28.83 & 29.42 & 28.52 & 65.61 & 64.97 & 5.56 & 5.61 & 44.45 & 44.02 & 3.89 & 3.86 & $\mathrm{~Tb}_{4} \mathrm{O}_{7}$ \\
\hline $\mathrm{Dy}(\mathrm{L})_{3} \cdot 2 \mathrm{H}_{2} \mathrm{O}$ & 28.60 & 28.92 & 28.87 & 65.87 & 65.53 & 5.53 & 5.55 & 44.21 & 44.44 & 3.87 & 3.89 & $\mathrm{Dy}_{2} \mathrm{O}_{3}$ \\
\hline $\mathrm{Ho}(\mathrm{L})_{3} \cdot 2 \mathrm{H}_{2} \mathrm{O}$ & 28.87 & 28.97 & 29.40 & 65.62 & 65.63 & 5.51 & 5.40 & 44.05 & 44.04 & 3.86 & 3.87 & $\mathrm{Ho}_{2} \mathrm{O}_{3}$ \\
\hline $\mathrm{Er}(\mathrm{L})_{3} \cdot 2 \mathrm{H}_{2} \mathrm{O}$ & 29.12 & 29.65 & 30.21 & 65.39 & 64.84 & 5.49 & 5.51 & 43.89 & 44.26 & 3.84 & 3.87 & $\mathrm{Er}_{2} \mathrm{O}_{3}$ \\
\hline $\mathrm{Tm}(\mathrm{L})_{3} \cdot 2 \mathrm{H}_{2} \mathrm{O}$ & 29.30 & 28.98 & 29.43 & 65.23 & 65.62 & 5.47 & 5.40 & 43.78 & 43.52 & 3.83 & 3.81 & $\mathrm{Tm}_{2} \mathrm{O}_{3}$ \\
\hline $\mathrm{Yb}(\mathrm{L})_{3} \cdot 2 \mathrm{H}_{2} \mathrm{O}$ & 29.74 & 29.95 & 30.08 & 64.82 & 64.48 & 5.44 & 5.57 & 43.51 & 43.74 & 3.81 & 3.82 & $\mathrm{Yb}_{2} \mathrm{O}_{3}$ \\
\hline $\mathrm{Lu}(\mathrm{L})_{3} \cdot 2 \mathrm{H}_{2} \mathrm{O}$ & 29.90 & 29.71 & 30.66 & 64.67 & 65.16 & 5.43 & 5.38 & 43.41 & 43.08 & 3.80 & 3.78 & $\mathrm{Lu}_{2} \mathrm{O}_{3}$ \\
\hline $\mathrm{Y}(\mathrm{L})_{3} \cdot 2 \mathrm{H}_{2} \mathrm{O}$ & 19.52 & 20.19 & 20.06 & 74.25 & 73.26 & 6.23 & 6.68 & 49.83 & 49.50 & 3.67 & 3.64 & $\mathrm{Y}_{2} \mathrm{O}_{3}$ \\
\hline
\end{tabular}

Ln: lanthanides(III) and yttrium(III); L: mandelate.

From X-ray powder patterns, Fig.1, all the compounds were obtained with low crystallinity degree, except for yttrium, probably due to the precipitation velocity which was not controlled. Due to the low cristallinity degree, it is very difficult to establish the formation of an isomorphous series. The X-ray powder patterns also show 
that the crystallinity of these compounds follows the order: $\mathrm{Y}>\mathrm{Lu}>\mathrm{Er} \cong \mathrm{Tm} \cong \mathrm{Yb} \cong \mathrm{Ho}>\mathrm{Tb} \cong \mathrm{Dy}$.

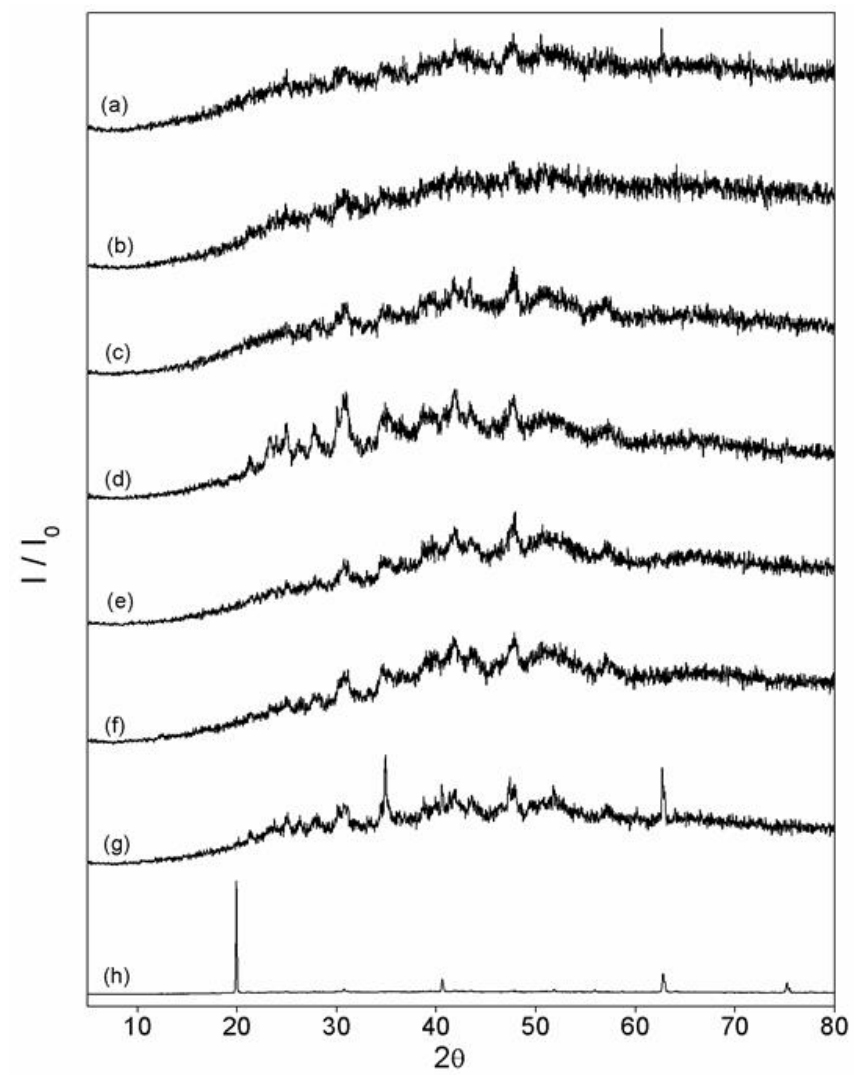

Figure 1 X-ray powder diffraction patterns of the compounds: (a) $\mathrm{Tb}(\mathrm{L})_{3} \cdot 2 \mathrm{H}_{2} \mathrm{O}$, (b) $\mathrm{Dy}(\mathrm{L})_{3} \cdot 2 \mathrm{H}_{2} \mathrm{O}$, (c) $\mathrm{Ho}(\mathrm{L})_{3} \cdot 2 \mathrm{H}_{2} \mathrm{O}$, (d) $\mathrm{Er}(\mathrm{L})_{3} \cdot 2 \mathrm{H}_{2} \mathrm{O}$, (e) $\mathrm{Tm}(\mathrm{L})_{3} \cdot 2 \mathrm{H}_{2} \mathrm{O}$, (f) $\mathrm{Yb}(\mathrm{L})_{3} \cdot 2 \mathrm{H}_{2} \mathrm{O}$, (g) $\mathrm{Lu}(\mathrm{L})_{3} \cdot 2 \mathrm{H}_{2} \mathrm{O}$ and (h) $\mathrm{Y}(\mathrm{L})_{3} \cdot 2 \mathrm{H}_{2} \mathrm{O}$. (L: mandelate).

The geometry optimization of the yttrium compound computed by the optimized algorithm of Berny can be seen in Fig. 2. It was shown that the yttrium compound in Fig. $2 b$ is $1.85,10.8$ and $2.79 \mathrm{kcal} \mathrm{mol}^{-1}$ more stable than its isomers in Fig. 2a, c and d, respectively. The main structure parameters obtained for the most stable compound (Fig. 2b) are shown in Table 2.

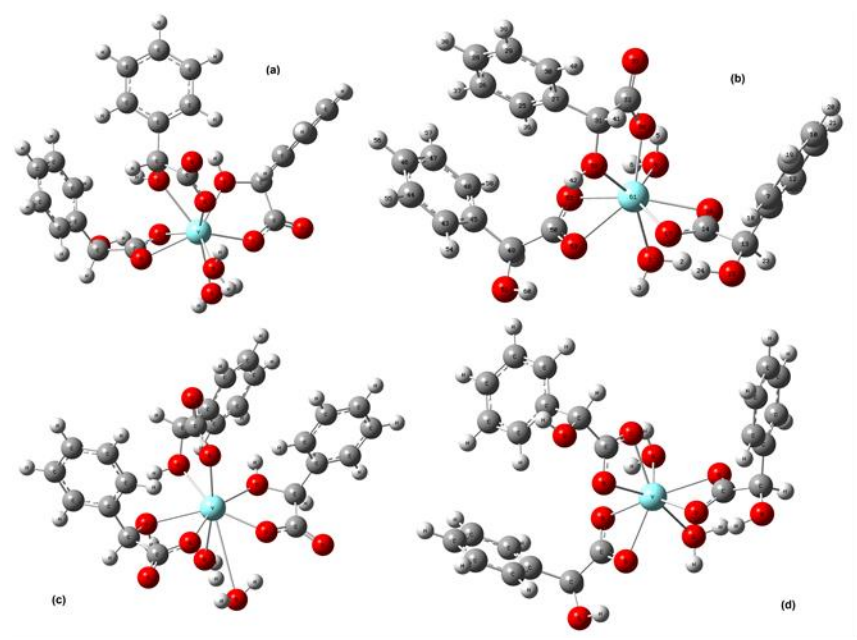

Figure 2 Theoretical 3D structure of $\mathrm{Y}(\mathrm{L})_{3} \cdot 2 \mathrm{H}_{2} \mathrm{O}$ : (a), (c) and (d) isomers (less stable); (b) yttrium(III) mandelate coordinated by hydroxyl and carboxylate groups (the most stable compound).
Table 2 Main theoretical geometry parameters of yttrium(III) complex with mandelate (related to the Fig. 2b).

\begin{tabular}{lc}
\hline \multicolumn{1}{c}{ Parameters } & $\mathbf{Y}$ \\
\hline $\mathrm{d} \mathrm{Y}_{61}-\mathrm{O}_{34}$ & $2.21 \AA$ \\
$\mathrm{d} \mathrm{Y}_{61}-\mathrm{O}_{33}$ & $2.38 \AA$ \\
$\mathrm{d} \mathrm{O}_{33}-\mathrm{C}_{31}$ & $1.47 \AA$ \\
$\mathrm{d} \mathrm{O} \mathrm{O}_{34}-\mathrm{C}_{32}$ & $1.31 \AA$ \\
$<\mathrm{Y}_{61}-\mathrm{O}_{33}-\mathrm{C}_{31}$ & $121.6^{\circ}$ \\
$<\mathrm{Y}_{61}-\mathrm{O}_{34}-\mathrm{C}_{32}$ & $130.3^{\circ}$ \\
$<\mathrm{O}_{33}-\mathrm{Y}_{61}-\mathrm{O}_{34}$ & $66.5^{\circ}$ \\
$\mathrm{d} \mathrm{Y}_{61}-\mathrm{O}_{53}$ & $2.42 \AA$ \\
$\mathrm{d} \mathrm{Y}_{61}-\mathrm{O}_{52}$ & $2.39 \AA$ \\
$\mathrm{d} \mathrm{O} \mathrm{O}_{52}-\mathrm{C}_{50}$ & $1.28 \AA$ \\
$\mathrm{d} \mathrm{O} \mathrm{O}_{53}-\mathrm{C}_{50}$ & $127 \AA$ \\
$<\mathrm{O}_{52}-\mathrm{Y}_{61}-\mathrm{O}_{53}$ & $2.38 \AA$ \\
$<\mathrm{O}_{52}-\mathrm{C}_{50}-\mathrm{O}_{53}$ & $1.28 \AA$
\end{tabular}

d: distance; <: angle.

The attenuated total reflectance infrared spectroscopic data on sodium mandelate, mandelic acid and mandelate compounds with the metal ions considered in this work are shown in Table 3. For yttrium compound, the main experimental infrared spectroscopic data were assigned based on the theoretical infrared one calculated and it is shown in Table 4. 
Table 3 Experimental spectroscopic data for sodium mandelate and its compounds with heavy trivalent lanthanide and yttrium(III) ions.

\begin{tabular}{|c|c|c|c|c|c|c|}
\hline Compounds & $\begin{array}{c}v(\mathrm{OH}) / \\
\mathrm{cm}^{-1}\end{array}$ & $\begin{array}{c}v_{\mathrm{as}}\left(\mathrm{COO}^{-}\right)^{\mathrm{a}} / \\
\mathrm{cm}^{-1}\end{array}$ & $\begin{array}{c}v_{\mathrm{s}}\left(\mathrm{COO}^{-}\right)^{\mathrm{b}} / \\
\mathrm{cm}^{-1}\end{array}$ & $\begin{array}{c}\Delta v \\
\mathrm{~cm}^{-1}\end{array}$ & $\begin{array}{c}\delta(\mathrm{O}-\mathrm{H})^{\mathrm{c}} / \\
\mathrm{cm}^{-1}\end{array}$ & $\begin{array}{c}v(\mathrm{C}-\mathrm{OH})^{\mathrm{d}} / \\
\mathrm{cm}^{-1}\end{array}$ \\
\hline HL & $3395 \mathrm{~m}$ & $1711_{\mathrm{s}}$ & - & - & $1377_{\mathrm{w}}$ & $1062 \mathrm{~m}$ \\
\hline $\mathrm{NaL}$ & $3458 \mathrm{~m}$ & $1606_{\mathrm{s}}$ & $1410_{\mathrm{m}}$ & 196 & $1358 \mathrm{~m}$ & $1065_{\mathrm{m}}$ \\
\hline $\mathrm{Tb}(\mathrm{L})_{3} \cdot 2 \mathrm{H}_{2} \mathrm{O}$ & $3205 \mathrm{~m}$ & $1595 \mathrm{~s}$ & $1406 \mathrm{~m}$ & 189 & $1379 \mathrm{~m}$ & $1033 \mathrm{~m}$ \\
\hline $\mathrm{Dy}(\mathrm{L})_{3} \cdot 2 \mathrm{H}_{2} \mathrm{O}$ & $3201 \mathrm{~m}$ & $1596 \mathrm{~s}$ & $1407 \mathrm{~m}$ & 189 & $1380 \mathrm{~m}$ & $1033 \mathrm{~m}$ \\
\hline $\mathrm{Ho}(\mathrm{L})_{3} \cdot 2 \mathrm{H}_{2} \mathrm{O}$ & $3209 \mathrm{~m}$ & $1597_{\mathrm{s}}$ & $1409 \mathrm{~m}$ & 188 & $1381 \mathrm{~m}$ & $1034_{\mathrm{m}}$ \\
\hline $\mathrm{Er}(\mathrm{L})_{3} \cdot 2 \mathrm{H}_{2} \mathrm{O}$ & $3216 \mathrm{~m}$ & $1598_{\mathrm{s}}$ & $1410_{\mathrm{m}}$ & 188 & $1382 \mathrm{~m}$ & $1034_{\mathrm{m}}$ \\
\hline $\mathrm{Tm}(\mathrm{L})_{3} \cdot 2 \mathrm{H}_{2} \mathrm{O}$ & $3219 \mathrm{~m}$ & $1598_{\mathrm{s}}$ & $1411_{\mathrm{m}}$ & 187 & $1383 \mathrm{~m}$ & $1035_{\mathrm{m}}$ \\
\hline $\mathrm{Yb}(\mathrm{L})_{3} \cdot 2 \mathrm{H}_{2} \mathrm{O}$ & $3219 \mathrm{~m}$ & $1599 \mathrm{~s}$ & $1412_{\mathrm{m}}$ & 187 & $1383 \mathrm{~m}$ & $1035_{\mathrm{m}}$ \\
\hline $\mathrm{Lu}(\mathrm{L})_{3} \cdot 2 \mathrm{H}_{2} \mathrm{O}$ & $3219 \mathrm{~m}$ & $1599 \mathrm{~s}$ & $1413_{\mathrm{m}}$ & 186 & $1385 \mathrm{~m}$ & $1035_{\mathrm{m}}$ \\
\hline $\mathrm{Y}(\mathrm{L})_{3} \cdot 2 \mathrm{H}_{2} \mathrm{O}$ & $3215 \mathrm{~m}$ & $1598 \mathrm{~s}$ & $1409 \mathrm{~m}$ & 189 & $1382 \mathrm{~m}$ & $1034 \mathrm{~m}$ \\
\hline
\end{tabular}

HL: mandelic acid; NaL: sodium mandelate; L: mandelate; m: medium; s: strong; w: weak.

${ }^{\mathrm{a}} \mathrm{v}_{\mathrm{as}}\left(\mathrm{COO}^{-}\right)$: antisymmetric carboxyl stretching frequency.

${ }^{\mathrm{b}} \mathrm{v}_{\mathrm{s}}\left(\mathrm{COO}^{-}\right)$: symmetric carboxyl stretching frequency.

${ }^{c} \delta(\mathrm{OH})$ : hydroxyl oxygen-hydrogen bending frequency.

${ }^{d} v(\mathrm{C}-\mathrm{OH})$ : carbon hydroxyl stretching frequency.

Table 4 Main experimental and theoretical (related to the Figure 2) infrared absorptions of $\mathrm{Y}(\mathrm{L})_{3} \cdot 2 \mathrm{H}_{2} \mathrm{O}$.

\begin{tabular}{|c|c|c|}
\hline \multirow{2}{*}{ Assignments } & \multicolumn{2}{|c|}{ Frequencies $\left(\mathrm{cm}^{-1}\right)$} \\
\hline & Experimental & Theoretical \\
\hline$v_{\mathrm{HOH} \text { (as) }}$ & $3215_{\mathrm{m}}$ & $3805_{\mathrm{w}}$ \\
\hline$\nu_{\mathrm{HOH} \text { (as) }}$ & Overlap, br & $3765_{\mathrm{w}}$ \\
\hline$v_{\mathrm{OH}}$ & Overlap, br & $3739_{w}$ \\
\hline$v_{\mathrm{HOH}(\mathrm{s})}$ & Overlap, br & $3682_{\mathrm{w}}$ \\
\hline$v_{\mathrm{OH}}$ & Overlap, br & $3640_{w}$ \\
\hline$v_{\mathrm{OH}}$ & Overlap, br & $3641_{\mathrm{w}}$ \\
\hline$v_{\mathrm{OH}}$ & Overlap, br & $3631_{\mathrm{w}}$ \\
\hline$v_{\mathrm{HOH}(\mathrm{s})}$ & Overlap, br & $3568_{w}$ \\
\hline$v_{\mathrm{as}(\mathrm{COO})}$ & $1598_{\mathrm{s}}$ & $1744_{s}$ \\
\hline$\delta_{\mathrm{OH}}$ & $1498_{\mathrm{w}}$ & $1618_{\mathrm{w}}$ \\
\hline$v_{\mathrm{as}(\mathrm{COO})}$ & Overlap & $1565_{\mathrm{m}}$ \\
\hline$v_{\mathrm{s}(\mathrm{COO})}$ & $1409_{\mathrm{m}}$ & $1444_{\mathrm{s}}$ \\
\hline$v_{\mathrm{s}(\mathrm{COO})}$ & Overlap & $1435_{\mathrm{s}}$ \\
\hline$\delta_{\mathrm{OH}}$ & $1382_{\mathrm{m}}$ & $1386_{\mathrm{m}}$ \\
\hline$\delta_{\mathrm{OH}}$ & $1284_{\mathrm{m}}$ & $1379_{\mathrm{m}}$ \\
\hline$v_{(\mathrm{CO})}$ & - & $1275_{\mathrm{m}}$ \\
\hline$\delta_{\mathrm{OH}}$ & $1277_{\mathrm{m}}$ & $1182_{\mathrm{m}}$ \\
\hline$v_{(\mathrm{C}-\mathrm{OH})}$ & $1034_{\mathrm{m}}$ & $1075_{\mathrm{m}}$ \\
\hline$v_{(\mathrm{C}-\mathrm{OH})}$ & Overlap & $1073_{\mathrm{m}}$ \\
\hline$v_{(\mathrm{C}-\mathrm{OH})}$ & Overlap & $987_{\mathrm{w}}$ \\
\hline
\end{tabular}

For sodium mandelate, the bands centered at $1606 \mathrm{~cm}^{-1}$ and $1410 \mathrm{~cm}^{-1}$ were assigned to antisymmetric $\left(v_{\mathrm{as}}\right.$ as $\left.\mathrm{COO}^{-}\right)$and symmetric $\left(\mathrm{v}_{\mathrm{s}} \mathrm{COO}^{-}\right)$carboxyl stretching frequencies, respectively. The values of $\Delta v\left(v_{\text {as }}\right.$ as $\mathrm{COO}^{-}-v_{\mathrm{s}}$ $\mathrm{COO}^{-}$, carboxylate vibrations) for the synthesized compounds are smaller than those ones calculated for the sodium salt (Table 3), suggesting that the coordination is carried out through the carboxylate group of the mandelate in a bidentate mode $[\underline{31}, \underline{32}]$ and in agreement with the theoretical calculation of yttrium compound (more stable molecule, Fig. 2b).

These results of the Table 3 also show that in all the compounds synthesized the $v(\mathrm{C}-\mathrm{OH})$ are shifted towards lower energy than those observed in the acid and in the sodium salt, suggesting that the $\mathrm{OH}$ group takes part of the coordination and they are in agreement with the references $[\underline{4}, \underline{5}]$. Thus, the coordination of the ligand can be carried out through the oxygen atoms of the carboxylate and the hydroxyl groups, as shown in Fig. 2b. The likeness between the experimental spectra of all the compounds suggests that they are coordinated in a similar way.

A comparative analysis between the theoretical (a) and experimental (b) data of the yttrium compound in Table 4 has shown that:

(i) the first assignment shows a strong contribution at $1598 \mathrm{~cm}^{-1}$ (broad band), suggesting an antisymmetric carboxyl stretching, while the theoretical results show the corresponding peak at $1744 \mathrm{~cm}^{-1}$ and $1565 \mathrm{~cm}^{-1}$ with discrepancies of $9.13 \%$ and $2.06 \%$, respectively; 
(ii) the second assignment shows a strong contribution at $1409 \mathrm{~cm}^{-1}$ suggesting a symmetric carboxyl stretching, while the theoretical results show the corresponding peak at $1444 \mathrm{~cm}^{-1}$ with discrepancy of $2.48 \%$. The theoretical results are therefore in agreement with the experimental data.

Simultaneous TG-DTA curves of the compounds are shown in Fig. 3. These curves exhibit mass losses in three,

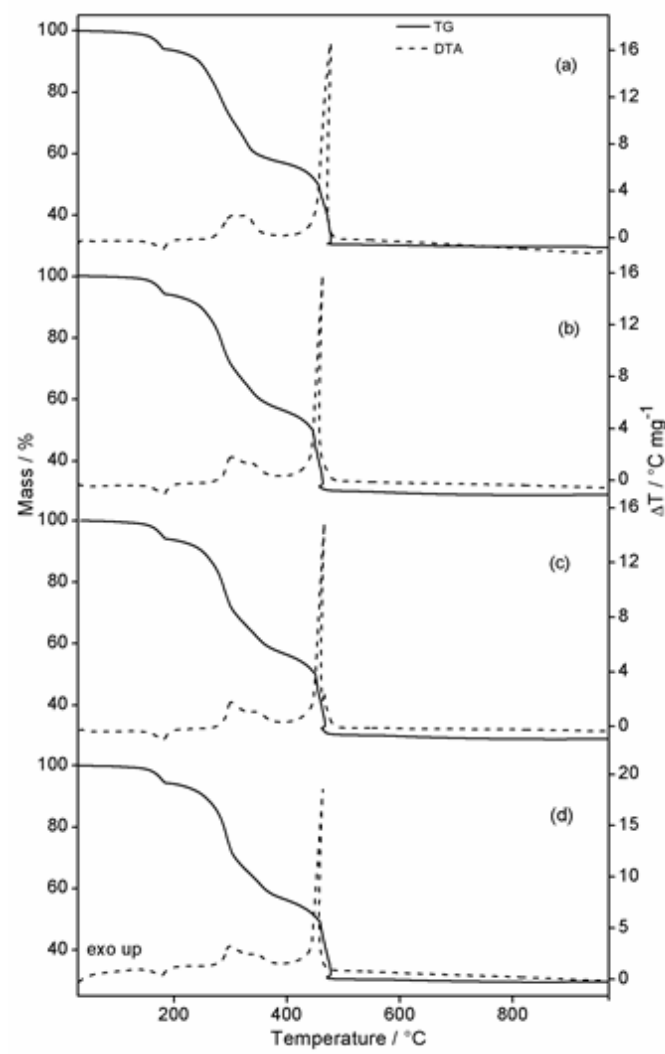

four or five consecutive and/or overlapping steps and thermal events corresponding to these losses. Three patterns of thermal behaviour are observed for these compounds. Firstly, a close similarity is noted concerning the TG-DTA profiles of the dysprosium, holmium, erbium and yttrium compounds, Fig. 3b, c, d and h. On the other hand, thulium, ytterbium and lutetium compounds display another set of very similar TG-DTA profiles, Fig. 3e, $f$ and $g$. On the contrary, terbium compound display another TG-DTA profiles, Fig. 3a.

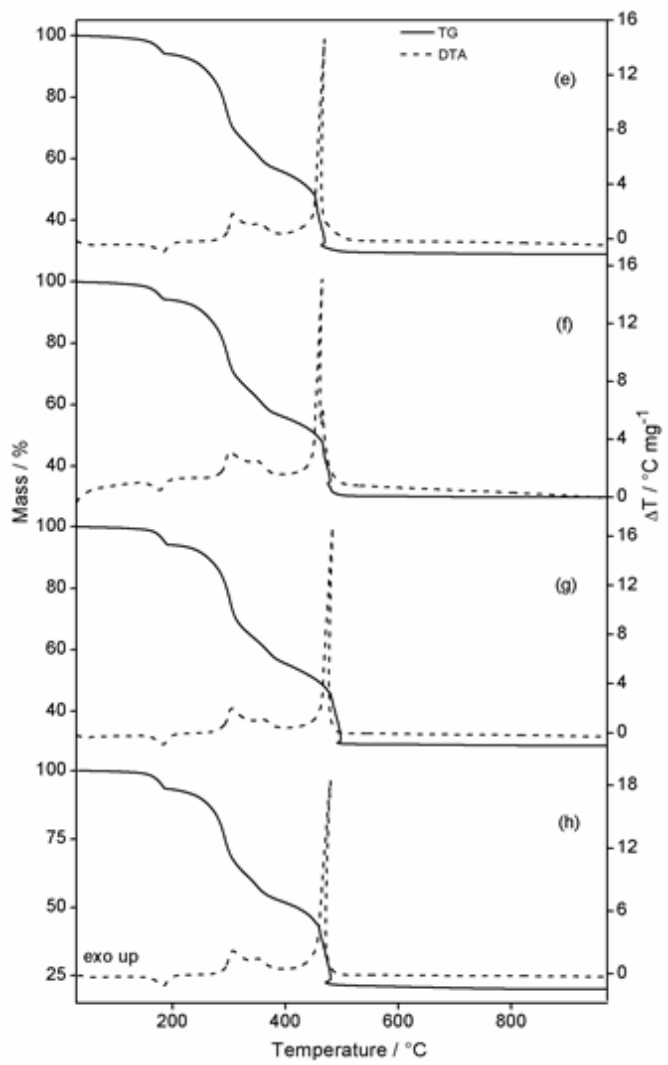

Figure 3 Simultaneous TG-DTA curves of the compounds: (a) $\mathrm{Tb}(\mathrm{L})_{3} \cdot 2 \mathrm{H}_{2} \mathrm{O}(\mathrm{m}=7.027 \mathrm{mg})$; (b) $\mathrm{Dy}(\mathrm{L})_{3} \cdot 2 \mathrm{H}_{2} \mathrm{O}(\mathrm{m}=7.076 \mathrm{mg})$; (c) $\mathrm{Ho}(\mathrm{L})_{3} \cdot 2 \mathrm{H}_{2} \mathrm{O}(\mathrm{m}=7.037 \mathrm{mg}) ;(\mathrm{d}) \mathrm{Er}(\mathrm{L})_{3} \cdot 2 \mathrm{H}_{2} \mathrm{O}(\mathrm{m}=7.210 \mathrm{mg}) ;\left(\right.$ e) $\mathrm{Tm}(\mathrm{L})_{3} \cdot 2 \mathrm{H}_{2} \mathrm{O}(\mathrm{m}=7.237 \mathrm{mg}) ;(\mathrm{f}) \mathrm{Yb}(\mathrm{L})_{3} \cdot 2 \mathrm{H}_{2} \mathrm{O}$ $(\mathrm{m}=7.047 \mathrm{mg}),(\mathrm{g}) \mathrm{Lu}(\mathrm{L})_{3} \cdot 2 \mathrm{H}_{2} \mathrm{O}(\mathrm{m}=7.021 \mathrm{mg})$ and $(\mathrm{h}) \mathrm{Y}(\mathrm{L})_{3} \cdot 2 \mathrm{H}_{2} \mathrm{O}(\mathrm{m}=7.152 \mathrm{mg})$. (L: mandelate).

The similarity observed in the TG-DTA profiles of some compounds (with three patterns of thermal behaviour) was not observed in the light trivalent lanthanide mandelates [13]. Thus, the features of each of these compounds are discussed on the base of their similar thermal profiles.

\section{Terbium compound}

The simultaneous TG-DTA curves are shown in Fig. 3a. The first mass loss observed between 70 and $195{ }^{\circ} \mathrm{C}$, corresponding to an endothermic peak at $180{ }^{\circ} \mathrm{C}$ is due to dehydration with loss of $2 \mathrm{H}_{2} \mathrm{O}$ (Calcd. $=5.56 \%$; $\mathrm{TG}=5.61 \%$ ). The thermal decomposition of the anhydrous compound occurs in two consecutive steps, corresponding to exothermic peaks attributed to oxidation of the organic matter which occurs with combustion. The total mass loss up to $480{ }^{\circ} \mathrm{C}$ is in agreement with the formation of terbium oxide, $\mathrm{Tb}_{4} \mathrm{O}_{7}$, as final residue $($ Calcd. $=71.17 \%$, $\mathrm{TG}=70.58 \%$ ).

\section{Dysprosium, holmium, erbium and yttrium compounds}

The simultaneous TG and DTA curves of the compounds are shown in Fig. $3 b-d$, h. For all the compounds, the first mass loss between 70 and $195{ }^{\circ} \mathrm{C}$, corresponding to an endothermic peak at $180{ }^{\circ} \mathrm{C}$ (Dy, Ho, Er) or $185{ }^{\circ} \mathrm{C}(\mathrm{Y})$ is due to dehydration, with loss of $2 \mathrm{H}_{2} \mathrm{O}$ (Calcd. $=5.53 \%$ (Dy), 5.51\% (Ho), 5.49\% (Er), 6.23\% (Y); $\mathrm{TG}=5.55 \%$ (Dy), $5.40 \%$ (Ho), 5.51\% (Er), 6.68\% (Y)). The thermal decomposition of the anhydrous compounds occurs in four consecutive and/or overlapping steps, being the first and third ones fast processes without a plateau between the steps, corresponding to exothermic peaks attributed to oxidation of the organic matter. The profiles of the TG-DTA also show that the oxidation of the organic matter occurs with combustion. The similarities of the TG-DTA curves also show that the thermal decomposition mechanism must be the same for these compounds. No thermal event corresponding to the last step is observed in the DTA curve; this is probably due to the small mass loss that occurs slowly and the heat involved in this step is not sufficient to produce a thermal event. The total mass loss up to $665{ }^{\circ} \mathrm{C}$ (Dy), $770{ }^{\circ} \mathrm{C}(\mathrm{Ho}), 720{ }^{\circ} \mathrm{C}(\mathrm{Er})$ and $700{ }^{\circ} \mathrm{C}(\mathrm{Y})$ is in agreement 
with the formation of the respective oxide, $\mathrm{Ln}_{2} \mathrm{O}_{3}$, as final residue $(\mathrm{Ln}=\mathrm{Dy}, \mathrm{Ho}, \mathrm{Er}, \mathrm{Y})$ as final residue.

\section{Thulium, ytterbium and lutetium compounds}

The simultaneous TG and DTA curves of the compounds are shown in Fig. 3e, f, g. The first mass loss between 70 and $195{ }^{\circ} \mathrm{C}$, for all the compounds, corresponding to an endothermic peak at $180{ }^{\circ} \mathrm{C}(\mathrm{Tm}, \mathrm{Yb})$ and $190{ }^{\circ} \mathrm{C}(\mathrm{Lu})$ is due to dehydration, with loss of $2 \mathrm{H}_{2} \mathrm{O}$ $($ Calcd. $=5.47 \%(\mathrm{Tm}), 5.44 \%(\mathrm{Yb}), 5.43 \%(\mathrm{Lu}) ; \mathrm{TG}=$ $5.40 \%(\mathrm{Tm}), 5.57 \%(\mathrm{Yb}), 5.38 \%(\mathrm{Lu}))$. The thermal decomposition of the anhydrous compounds occurs in three consecutive and/or overlapping steps. The first and third steps also occur through a fast process without a plateau between the steps, corresponding to exothermic peaks attributed to oxidation of the organic matter, which occurs with combustion, too. The total mass loss up to $550{ }^{\circ} \mathrm{C}$ $(\mathrm{Tm}), 500{ }^{\circ} \mathrm{C}(\mathrm{Yb})$ and $600{ }^{\circ} \mathrm{C}(\mathrm{Lu})$ is in agreement with the formation of the respective oxide, $\mathrm{Ln}_{2} \mathrm{O}_{3}$, as final residue $(\mathrm{Ln}=\mathrm{Tm}, \mathrm{Yb}, \mathrm{Lu})$ as final residue. No intermediate derivative of carbonate was observed in the thermal decomposition of these compounds, as observed for the lanthanum mandelate [13] and for other compounds of lanthanides with organic ligand containing carboxylic group [33]. The temperature ranges $(\theta)$, mass losses $(\mathrm{m})$ and peak temperatures $\left(\mathrm{T}_{\mathrm{p}}\right)$ observed for each step of the TG-DTA curves are shown in Table 5.

Table 5 Temperature ranges $(\theta)$, mass losses $(\Delta \mathrm{m})$ and peak temperatures $\left(\mathrm{T}_{\mathrm{p}}\right)$ observed for each step of TG-DTA curves of the compounds.

\begin{tabular}{|c|c|c|c|c|c|c|}
\hline \multirow{2}{*}{\multicolumn{2}{|c|}{ Compounds }} & \multicolumn{5}{|c|}{ TG Steps } \\
\hline & & First & Second & Third & Fourth & Fifth \\
\hline $\mathrm{Tb}(\mathrm{L})_{3} \cdot 2 \mathrm{H}_{2} \mathrm{O}$ & $\begin{array}{c}\theta /{ }^{\circ} \mathrm{C} \\
\Delta \mathrm{m} / \% \\
\mathrm{~T}_{\mathrm{p}} /{ }^{\circ} \mathrm{C}\end{array}$ & $\begin{array}{c}70-190 \\
5.61 \\
180(*)\end{array}$ & $\begin{array}{c}200-345 \\
34.36 \\
306 ; 335(* *)\end{array}$ & $\begin{array}{c}345-480 \\
30.61 \\
480(* *)\end{array}$ & - & - \\
\hline $\mathrm{Dy}(\mathrm{L})_{3} \cdot 2 \mathrm{H}_{2} \mathrm{O}$ & $\begin{array}{c}\theta /{ }^{\circ} \mathrm{C} \\
\Delta \mathrm{m} / \% \\
\mathrm{~T}_{\mathrm{p}} /{ }^{\circ} \mathrm{C}\end{array}$ & $\begin{array}{c}70-190 \\
5.55 \\
180(*)\end{array}$ & $\begin{array}{c}200-305 \\
23.28 \\
305(* *)\end{array}$ & $\begin{array}{c}305-360 \\
11.98 \\
340(* *)\end{array}$ & $\begin{array}{c}360-460 \\
28.94 \\
460(* *)\end{array}$ & $\begin{array}{c}460-665 \\
1.33 \\
-\end{array}$ \\
\hline $\mathrm{Ho}(\mathrm{L})_{3} \cdot 2 \mathrm{H}_{2} \mathrm{O}$ & $\begin{array}{c}\theta /{ }^{\circ} \mathrm{C} \\
\Delta \mathrm{m} / \% \\
\mathrm{~T}_{\mathrm{p}} /{ }^{\circ} \mathrm{C}\end{array}$ & $\begin{array}{c}70-190 \\
5.40 \\
180(*)\end{array}$ & $\begin{array}{c}200-310 \\
23.82 \\
305(* *)\end{array}$ & $\begin{array}{c}310-370 \\
11.64 \\
340(* *)\end{array}$ & $\begin{array}{c}370-470 \\
28.32 \\
470(* *)\end{array}$ & $\begin{array}{c}470-770 \\
1.85 \\
-\end{array}$ \\
\hline $\mathrm{Er}(\mathrm{L})_{3} \cdot 2 \mathrm{H}_{2} \mathrm{O}$ & $\begin{array}{c}\theta /{ }^{\circ} \mathrm{C} \\
\Delta \mathrm{m} / \% \\
\mathrm{~T}_{\mathrm{p}} /{ }^{\circ} \mathrm{C}\end{array}$ & $\begin{array}{c}70-190 \\
5.51 \\
180(*)\end{array}$ & $\begin{array}{c}200-315 \\
26.55 \\
310(* *)\end{array}$ & $\begin{array}{c}315-375 \\
11.18 \\
360(* *)\end{array}$ & $\begin{array}{c}375-480 \\
28.12 \\
480(* *)\end{array}$ & $\begin{array}{c}480-720 \\
1.01 \\
-\end{array}$ \\
\hline $\mathrm{Tm}(\mathrm{L})_{3} \cdot 2 \mathrm{H}_{2} \mathrm{O}$ & $\begin{array}{c}\theta /{ }^{\circ} \mathrm{C} \\
\Delta \mathrm{m} / \% \\
\mathrm{~T}_{\mathrm{p}} /{ }^{\circ} \mathrm{C}\end{array}$ & $\begin{array}{c}70-190 \\
5.40 \\
180(*)\end{array}$ & $\begin{array}{c}200-310 \\
25.19 \\
305(* *)\end{array}$ & $\begin{array}{c}310-375 \\
11.27 \\
355(* *)\end{array}$ & $\begin{array}{c}375-550 \\
29.16 \\
470(* *)\end{array}$ & - \\
\hline $\mathrm{Yb}(\mathrm{L})_{3} \cdot 2 \mathrm{H}_{2} \mathrm{O}$ & $\begin{array}{c}\theta /{ }^{\circ} \mathrm{C} \\
\Delta \mathrm{m} / \% \\
\mathrm{~T}_{\mathrm{p}} /{ }^{\circ} \mathrm{C}\end{array}$ & $\begin{array}{c}70-190 \\
5.57 \\
180(*)\end{array}$ & $\begin{array}{c}200-315 \\
25.79 \\
310(* *)\end{array}$ & $\begin{array}{c}315-375 \\
10.75 \\
365(* *)\end{array}$ & $\begin{array}{c}375-500 \\
27.94 \\
477 ; 482(* *)\end{array}$ & - \\
\hline $\mathrm{Lu}(\mathrm{L})_{3} \cdot 2 \mathrm{H}_{2} \mathrm{O}$ & $\begin{array}{c}\theta /{ }^{\circ} \mathrm{C} \\
\Delta \mathrm{m} / \% \\
\mathrm{~T}_{\mathrm{p}} /{ }^{\circ} \mathrm{C}\end{array}$ & $\begin{array}{c}70-195 \\
5.38 \\
190(*)\end{array}$ & $\begin{array}{c}200-320 \\
26.33 \\
315(* *)\end{array}$ & $\begin{array}{c}320-390 \\
11.19 \\
375(* *)\end{array}$ & $\begin{array}{c}390-600 \\
27.64 \\
500(* *)\end{array}$ & - \\
\hline $\mathrm{Y}(\mathrm{L})_{3} \cdot 2 \mathrm{H}_{2} \mathrm{O}$ & $\begin{array}{c}\theta /{ }^{\circ} \mathrm{C} \\
\Delta \mathrm{m} / \% \\
\mathrm{~T}_{\mathrm{p}} /{ }^{\circ} \mathrm{C}\end{array}$ & $\begin{array}{c}70-195 \\
6.68 \\
185(*)\end{array}$ & $\begin{array}{c}200-305 \\
25.38 \\
307(* *)\end{array}$ & $\begin{array}{c}305-360 \\
12.44 \\
350(* *)\end{array}$ & $\begin{array}{c}360-480 \\
31.82 \\
480(* *)\end{array}$ & $\begin{array}{c}480-700 \\
3.64 \\
-\end{array}$ \\
\hline
\end{tabular}

L: mandelate; $(*)$ : endothermic event; $(* *)$ : exothermic event.

The DSC curves of the compounds up to $300^{\circ} \mathrm{C}$ are shown in Fig. 4. These curves show endothermic peaks attributed to dehydration and corresponding to the first mass loss displayed by the TG curves. The endothermic peak at
$187{ }^{\circ} \mathrm{C}(\mathrm{Tb}, \mathrm{Dy}, \mathrm{Lu})$ and $186{ }^{\circ} \mathrm{C}(\mathrm{Ho}, \mathrm{Er}, \mathrm{Tm}, \mathrm{Yb})$ and $190{ }^{\circ} \mathrm{C}$ (Y) is due to dehydration. The dehydration enthalpies found for these compounds were: $108.3(\mathrm{~Tb})$, 110.8 (Dy), 111.8 (Ho), 115.6 (Er), 111.9 (Tm), 116.3 (Yb), 
$121.3(\mathrm{Lu})$ and $125.3(\mathrm{Y}) \mathrm{kJ} \mathrm{mol}^{-1}$. Small differences observed concerning the peak temperatures obtained by TGDTA and DSC are undoubtedly due to perforated cover used to obtain the DSC curves, while the TG-DTA ones are obtained without cover.
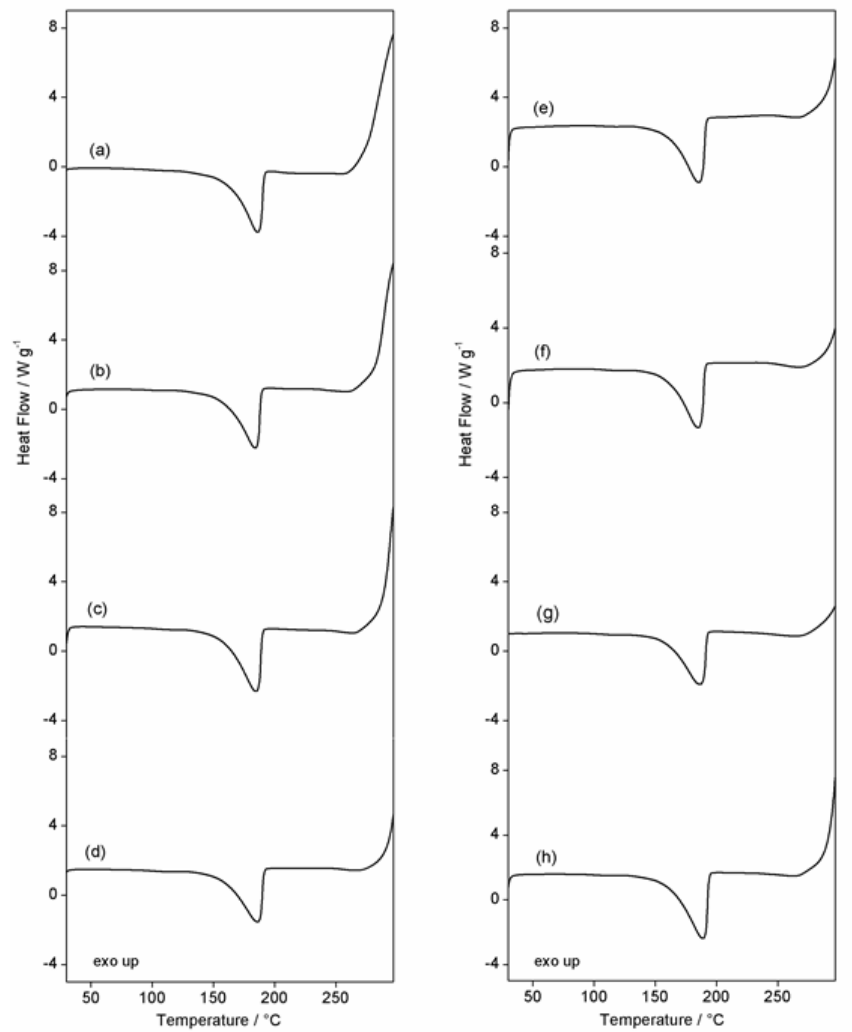

Figure 4 DSC curves of the compounds: (a) $\mathrm{Tb}(\mathrm{L})_{3} \cdot 2 \mathrm{H}_{2} \mathrm{O}$ $(\mathrm{m}=2.239 \mathrm{mg})$, (b) $\mathrm{Dy}(\mathrm{L})_{3} \cdot 2 \mathrm{H}_{2} \mathrm{O}(\mathrm{m}=2.138 \mathrm{mg})$, (c) $\mathrm{Ho}(\mathrm{L})_{3} \cdot 2 \mathrm{H}_{2} \mathrm{O} \quad(\mathrm{m}=2.273 \mathrm{mg}), \quad(\mathrm{d}) \quad \mathrm{Er}(\mathrm{L})_{3} \cdot 2 \mathrm{H}_{2} \mathrm{O}$ $(\mathrm{m}=2.099 \mathrm{mg}),(\mathrm{e}) \mathrm{Tm}(\mathrm{L})_{3} \cdot 2 \mathrm{H}_{2} \mathrm{O}(\mathrm{m}=2.704 \mathrm{mg})$ and (f) $\mathrm{Yb}(\mathrm{L})_{3} \cdot 2 \mathrm{H}_{2} \mathrm{O} \quad(\mathrm{m}=2.308 \mathrm{mg}), \quad(\mathrm{g}) \mathrm{Lu}(\mathrm{L})_{3} \cdot 2 \mathrm{H}_{2} \mathrm{O}$ $(\mathrm{m}=2.062 \mathrm{mg})$ and $(\mathrm{h}) \mathrm{Y}(\mathrm{L})_{3} \cdot 2 \mathrm{H}_{2} \mathrm{O}(\mathrm{m}=2.192 \mathrm{mg})$. (L: mandelate).

The gaseous products evolved during the thermal decomposition of terbium to lutetium and yttrium mandelates were monitored by FTIR and they have benzaldehyde, carbon monoxide and carbon dioxide as main products due to decarboxylation and oxidation of the organic matter. The infrared spectra of the gaseous products evolved during the thermal decomposition of dysprosium mandelate, as representative of all the compounds studied in this work, are shown in Fig. 5

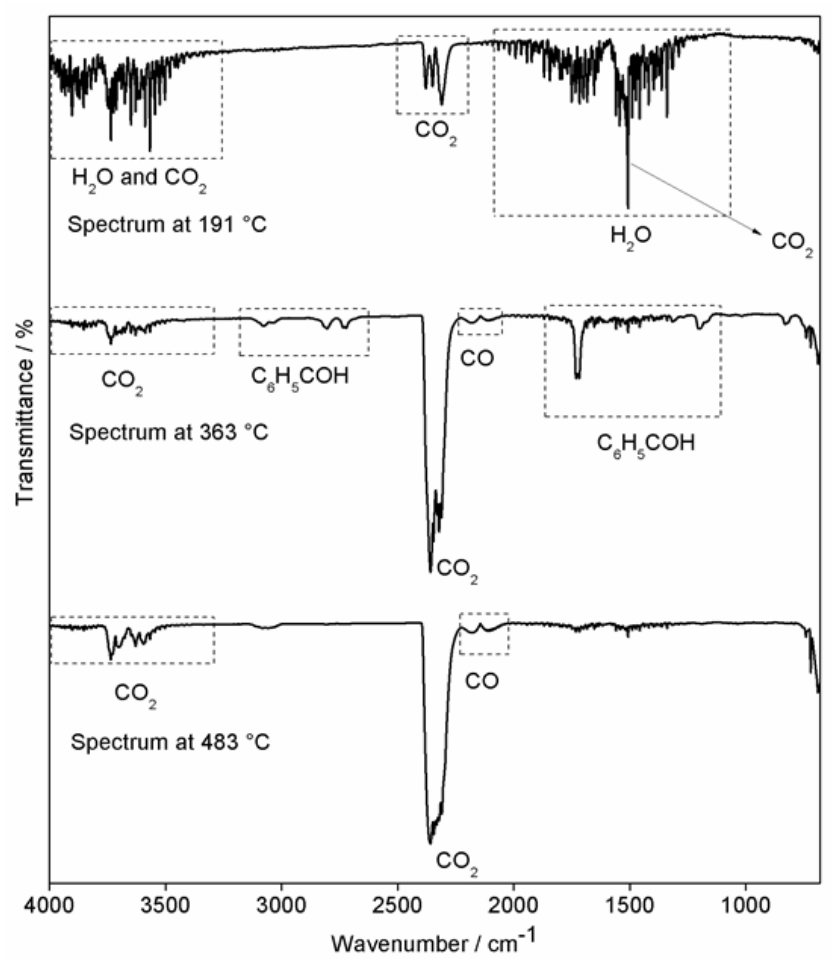

Figure 5 IR spectra of the gaseous products evolved during the thermal decomposition of dysprosium compound.

\section{Conclusion}

From TG, complexometry and elemental analysis data, a general formula could be established for these compounds involving heavy trivalent lanthanides and yttrium mandelates.

The experimental spectroscopic infrared data and the theoretical calculations suggest that the binding of the ligand to the heavy lanthanide(III) and yttrium(III) ions is performed in a bidentate mode through the oxygen of the carboxylate and hydroxyl groups. The similarity between the experimental infrared spectra suggests that all the compounds are coordinated in a similar way.

The TG-DTA curves show that all the compounds were obtained as dehydrated and the dehydration occurs in a single step within the same temperature range. These curves also show that the thermal decomposition of these compounds occurs in the same temperature and the features as well as the mass lost in each step are characteristic of each compound.

The monitoring of evolved gases during the thermal decomposition of these compounds showed that they have benzaldehyde, carbon dioxide and carbon monoxide as main products.

\section{Acknowledgements}

The authors thank FAPESP, CNPq and CAPES foundations (Brazil) for financial support.

This research was supported by resources supplied by the Center for Scientific Computing (NCC/GridUNESP) of Universidade Estadual Paulista (UNESP), Instituto de 
Química - Campus de Araraquara and CENAPADUNICAMP.

\section{References}

[1] Thun H, Verbeek F, Vanderleen W. The stability of some lanthanide complexes with mandelate and atrolactate. J Inorg Nucl Chem. 1966;28:1949-54.

[2] Dagdar A, Choppin GR. The complexation of lanthanide ions with mandelate. J Inorg Nucl Chem. 1972;34:1297-1301.

[3] Plyushchev VE, Nadezhdina GV, Loseva GS, Podkopaeva IV. Lanthanum, neodymium and yttrium mandelates. Khimi Khim Tekhnol. 1972;15(3):44749.

[4] Krasovskaya TA, Pirkes SB. Synthesis and study of the properties of yttrium subgroup rare earth phenylhydroxyacetates. Z Noorg Khim. 1972;17(6):1509-12.

[5] [5] Koppikar DK, Soundararajan S. Bonding trends in lanthanides mandelates. Bull Soc Chim Belges. 1981;90(11):1109-14.

[6] Powell JE, Neillie WFS. The successive formation constants and proposed models of the lighter lanthanide mandelates. J Inorg Nucl Chem. 1967;29:2371-75.

[7] Yanping R, Li Z, Kaiyu Y, Yu L, Liufang W. Calorimetric titration of complexation of seven lanthanide mandelates with 1,10-phenanthroline. Polyhedron. 1996;15(13):2231-35.

[8] Yanping R, Li Z. Studies on the kinetics of complexation of seven lanthanide mandelates with 1,10-phenanthroline. Synth React Inorg Met-Org Chem. 1999;29(4):599-606.

[9] Lin M, Yan S, Yang Y, Pan W. Preparation and structural analysis of lanthanide complexes with $\alpha$ hydroxy-phenyl-acetic acid and 1,10-phenanthroline as ligands. J Donghua Univ. 2008;25(3):340-4.

[10] Bromant C, Nika W, Pantenburg I, Meyer G. Synthesis and crystal structures of $\operatorname{Pr}(\operatorname{Man}) 3(\mathrm{ManH})$ and Er(Man)3(H2O)2. Z Naturforsch, B: J Chem Sci. 2005;60(7):753-7.

[11] Babij M, Mondry A. Synthesis, structure and spectroscopic studies of europium complex with S(+)-mandelic acid, J Rare Earths. 2011;29(12):118891.

[12] Babij M, Starynowicz P, Mondry A. Structural and spectroscopic studies of neodymium complexes with S(+)-mandelic acid. J Mol Struc. 2011;1006:672-7.

[13] Gigante AC, Gomes DJC, Lima LS, Caires FJ, TreuFilho O, Ionashiro M. Synthesis, thermal properties and spectroscopic study of solid mandelate of light trivalent lanthanides. Thermochim Acta. 2012;536:614.

[14] Lima LS, Caires FJ, Carvalho CT, Siqueira AB, Ionashiro M. Synthesis, characterization and thermal behaviour of solid-state compounds of light trivalent lanthanide succinates. Thermochim Acta. 2010;501:50-4.

[15] Lima LS, Caires FJ, Gigante AC, Gomes DJC, Siqueira AB, Carvalho CT, Ionashiro M. Synthesis, characterization and thermal behavior of solid state compounds of heavy trivalent lanthanide succinates. Thermochim Acta. 2013;557:31-6.

[16] Ambrozini B, Dametto PR, Siqueira AB, Carvalho CT, Ionashiro M. Synthesis, characterization and thermal behavior on solid tartrates of light trivalent lanthanides. J Therm Anal Calorim. 2009;97:761-4.

[17] B. Ambrozini, P.R. Dametto, M. Ionashiro, Synthesis, characterization and thermal behaviour of solid-state tartrates of heavy trivalent lanthanides and yttrium(III), J. Therm. Anal. Calorim. 105 (2011) 867-871.

[18] Siqueira AB, Carvalho CT, Rodrigues EC, Ionashiro EY, Bannach G, Ionashiro M. Synthesis, characterization and thermal behaviour of heavy lanthanide and yttrium pyruvates in the solid state. J Therm Anal Calorim. 2010;100:95-100.

[19] Siqueira AB, Carvalho CT, Rodrigues EC, Ionashiro EY, Bannach G, Ionashiro M. Synthesis, characterization and thermal behaviour on solid pyruvates of light trivalent lanthanides. Ecl Quim. 2007;32(4):49-54.

[20] Flaschka HA. EDTA Titrations: an introduction to theory and practice. 2nd ed. Oxford: Pergamon Press; 1964.

[21] Ionashiro M, Graner CAF, Zuanon Netto J. Titulação complexométrica de lantanídeos e ítrio. Ecl Quim. 1983;8:29-32.

[22] Becke AD. Density-functional thermochemistry. III. The role of exact exchange. J Chem Phys. 1993;98:5648-52.

[23] Lee C, Yang W, Parr RG. Development of the collesalvetti correlation benergy formula into a functional of the electrondensity. Phys Rev B.1988;37:785-89.

[24] Treu-Filho O, Pinheiro JC, da Costa EB, Ferreira JEV, de Figueiredo AF, Kondo RT, de Lucca Neto VA, de Souza RA, Legendre AO, Mauro AE. Experimental and theoretical study of the compound [Pd(dmba)(NCO)(imz)]. J Mol Struct. 2007;829:195201. 
[25] Treu-Filho O, Pinheiro JC, Kondo RT, Marques RFC, Paiva-Santos CO, Davolos MR, Jafelicci Jr. M. Gaussian basis sets to the theoretical study of the electronic structure of perovskite (LaMnO3). J Mol Struc (Theochem). 2003;631:93-9.

[26] Treu-Filho O, Pinheiro JC, Kondo RT. Designing Gaussian basis sets to the theoretical study of the piezoelectric effect of perovskite (BaTiO3). J Mol Struct. 2004;671:71-5.

[27] Frisch MJ, Trucks GW, Schlegel HB, Scuseria GE, Robb MA, Cheeseman JR, Scalmani G, Barone V, Mennucci B, Petersson GA, Nakatsuji H, Caricato M, Li X, Hratchian HP, Izmaylov AF, Bloino J, Zheng G, Sonnenberg JL, Hada M, Ehara M, Toyota K, Fukuda R, Hasegawa J, Ishida M, Nakajima T, Honda Y, Kitao O, Nakai H, Vreven T, Montgomery JA, Jr., Peralta JE, Ogliaro F, Bearpark M, Heyd JJ, Brothers E, Kudin KN, Staroverov VN, Kobayashi R, Normand J, Raghavachari K, Rendell A, Burant JC, Iyengar SS, Tomasi J, Cossi M, Rega N, Millam JM, Klene M, Knox JE, Cross JB, Bakken V, Adamo C, Jaramillo J, Gomperts R, Stratmann RE, Yazyev O, Austin AJ, Cammi R, Pomelli C, Ochterski JW, Martin RL, Morokuma K, Zakrzewski VG, Voth GA, Salvador P, Dannenberg JJ, Dapprich S, Daniels AD, Farkas Ö, Foresman JB, Ortiz JV, Cioslowski J, Fox DJ. Gaussian 09. Revision A. 02. Gaussian Inc.: Wallingford CT;2009.

[28] Goodson DZ, Sarpal SK, Wolfsberg M. Influence on isotope effect calculations of the method of obtaining force constants from vibrational data. J Phys Chem. 1982;86:659-63.

[29] Schelegel HB. in: J. Bertran (Ed.). New Theoretical Concepts for Understanding Organic Reactions. Academic: The Netherlands,1989:33-53.

[30] Dennington R, Keith T, Millam J. GaussView. Version 5. 0. 8. Semichem Inc.: Shawnee Mission KS, 2000-2008.

[31] Nakamoto K. Infrared and Raman Spectra of Inorganic and Coordination Compounds, Part B. 5th ed. New York: Wiley, 1997, pp. 58-61.

[32] Deacon GB, Phillips RJ. Relationships between the carbon-oxygen stretching frequencies of carboxylato complexes and the type of carboxylate coordination. Coord Chem Rev. 1980;33:227-50.

[33] Marques RN, Melios CB, Ionashiro M. Synthesis, characterization and thermal behaviour of solid state compounds of 4-methylbenzylidenepyruvate with heavier trivalent lanthanides and yttrium (III). Thermochim Acta. 2003;395:145-50. 